\title{
Devadesátník Miroslav Grepl
}

Jakkoliv se to zdá neuveřitelné, dne 14. dubna letošního roku oslavil devadesáté narozeniny emeritní profesor Filozofické fakulty Masarykovy univerzity PhDr. Miroslav Grepl, CSc. Rodák z hanáckého Hrochova získal středoškolské vzdělání na českobudějovickém reálném gymnáziu, kde se mimo jiné intenzivně zajímal o národní literatury Slovanů. V důsledku tohoto zájmu se pak v roce 1949 zapsal ke studiu české a ruské filologie na Filozofické fakultě Masarykovy univerzity. Mezi jeho učitele patřili soudobí přední specialisté oboru - bohemista Adolf Kellner, indoevropeista Václav Machek, paleoslovenista Josef Kurz, rusista Bořivoj Novák či bohemista a slavista František Trávníček. Po úspěšném absolvování v roce 1953 se stal jedním z prvních interních aspirantů Františka Trávníčka a začal zpracovávat kandidátskou disertaci, která cílila na rozbor gramatické stavby prozaického díla Josefa Kajetána Tyla z třicátých a čtyřicátých let devatenáctého století. Na jejím základě pak v roce 1959 obhájil oba doktorské tituly. Po úspěšném zakončení postgraduálního studia zůstal zaměstnancem katedry a začal se připravovat $\mathrm{k}$ habilitaci spisem ze synchronní jazykovědy, v němž vyšetřil mody a formy vyjadřování emocionality ve struktuře výpovědi. Habilitační práci úspěšně obhájil a počátkem roku 1966 byl jmenován docentem českého jazyka. Uvedená studie pak o rok později vyšla knižně pod názvem Emocionálně motivované aktualizace $v$ syntaktickéstruktuře výpovědi. Titul profesora mu byl přiznán těsně po Sametové revoluci, titul DrSc., pro jehož získání splnil všechny požadavky, ale vinou mimovědeckých okolností mu udělen nebyl, se již po nástupu nových poměrů nesnažil obhájit.

Miroslav Grepl se na počátku své kariéry orientoval na zkoumání obrozenecké morfosyntaxe a jazykové normy. Na materiálu Tylových próz probádal sémantiku spojek an a však ale, distribuci staršího předmětového genitivu v kontrastu s novějším akuzativem či proměny slovosledu, v globálním pohledu se pak zaměřil na stylovou diferenciaci obrozeneckých spojek a jednotlivé stupně vývoje spisovného jazyka první poloviny devatenáctého století. Cenné jsou také jeho poznatky o silném vlivu polštiny a ruštiny na syntaktickou stavbu češtinu, podložené bohatým materiálem.

Jubilantův celoživotní zájem o literaturu měl pak za následek, že parciálně zasahoval také do textologie. Spolu s literárním teoretikem a historikem Karlem Palasem připravili kritické vydání několika kanonických děl české literatury, např. Lišky Bystroušky od Rudolfa Těsnohlídka nebo Pohádky máje Viléma Mrštíka.

Největší díl práce Miroslav Grepl vykonal v oblasti synchronní syntaxe. Spolu s Jaroslavem Bauerem participoval na proslulých brněnských syntaktických symposiích Otázky slovanskésyntaxe, konaných mezi lety 1961 a 1976, a po Bauerově smrti se stal jejich hlavní hybnou 
silou. Se stejným spoluautorem pak sepsal ve své době novátorsky pojatou, dnes klasickou publikaci Skladba spisovné čěstiny. Ta poprvé vyšla v roce 1964 a snažila se ve svém výkladu propojit výsledky nejnovějších vědeckých observací se školsky pojatým a kondenzovaným výkladem skladby v České mluvnici Bohuslava Havránka a Aloise Jedličky. Od tř́ soudobých syntaktických popisů se od počátků zásadně lišila - deskripci novočeské skladby Františka Trávníčka, podanou v druhém díle jeho Mluvnice spisovné češtiny, předčila použitím vědecké metodologie a přehledností, oproti práci Vladimíra Šmilauera Novočeská skladba tolik neakcentovala formalizaci a zabývala se i funkcí synsémantik a na rozdíl od knihy Františka Kopečného Základy české skladby, která byla původně koncipována jako komentář k dvěma uvedeným publikacím, neobsahovala výklady historické a kontrastivní. Skladba spisovné čéštiny se stala oblíbenou a vyhledávanou syntaktickou př́ručkou a do roku 1980 se dočkala celkem šesti vydání. Potřeba aktualizovat výklad v souladu s nejnovějšími podněty tehdejší moderní lingvistiky přivedla Miroslava Grepla k štastnému rozhodnutí nahradit svého zesnulého kolegu svým nejvýraznějším žákem a mladším kolegou Petrem Karlíkem. Autorský tandem, který již v roce 1983 přetavil svůj potenciál v úspěšnou a originální monografii o deagentizaci a dekauzativizaci Gramatické prostředky hierarchizace sémantické struktury věty, přinesl pod původním názvem osobitý syntaktický popis rozšířený o pohled pragmatický. Publikace byla navíc zpracována v duchu Greplova postulátu konstruovat gramatiku od výrazu k významu a zase zpět k výrazu. Zájem o periferní a často nespisovné syntaktické jevy měl za následek, že při jejím posledním vydání (1998) vypustili autoři z názvu atribut spisovná.

Nezanedbatelné místo mezi vědeckými aktivitami Miroslava Grepla zaujímá jeho funkce vědeckého sekretáře Mezinárodní komise pro studium gramatické stavby slovanských jazyků při Mezinárodním komitétu slavistů. Z jejího titulu se účastnil diskusí o gramatickém popisu jednotlivých slovanských jazyků a díky tomu nejen čerpal poznatky o nejnovejšśch způsobech syntaktického bádání, ale také navázal mnohá pevná přátelství a ostatní mezilidské vztahy. Logicky se pak stal členem autorského kolektivu, který zpracoval koncepci české akademické mluvnice. Koncepce vyšla pod názvem Teoretické základy synchronní mluvnice spisovné češtiny (1975) a jejími spolutvůrci byli František Daneš, Karel Hausenblas, Zdeněk Hlavsa, Miroslav Komárek, Jan Kořenský a Roman Mrázek. O dvanáct let později vznikl na jejím základě tř̌etí svazek Mluvnice češtiny s podtitulem Skladba, jejž Miroslav Grepl koeditoval a do něhož zpracoval výklady o modalitě, komunikativní funkci výpovědi a společně s Petrem Karlíkem i kapitolu o hierarchizaci propozice. S Petrem Karlíkem a Markem Nekulou pak také sepsali př́slušné syntaktické výklady pro brněnskou Př́ruční mluvnici češtiny (1995). Opodál nezůstal ani při tvorbě dalšího zásadního projektu české bohemistiky - Encyklopedického slovníku češtiny (2002).

Greplovy ojedinělé návrhy aktualizovat a rozvolnit jazykovou normu, fragmentárně představené na různých konferencích či na neformálních setkáních, se jeví jako př́liš geniální pro tento svět a na všeobecné uznání ze strany širší odborné veřejnosti zatím čekají. Přejeme Miroslavu Greplovi i do dalších let pevné zdraví a bystrou mysl a těšíme se na jeho další př́spěvky vedoucí $\mathrm{k}$ lepšímu poznání českého jazyka. 


\section{Petr Malč́k}

Czech Language Institute of the CAS, v. v. i.

Veveří 97, 602 oo Brno

Czech Republic

petrmalcik@yahoo.com licence nebo výjimky či omezení př́slušných práv. 